\title{
Assessment of Engineering Properties of Al-Haweri Scoria, NW Sana'a, Yemen
}

\author{
Ibrahim A. Al-Akhaly ${ }^{1} \mathbb{D}$, Abubaker A. Al-Sakkaf ${ }^{2} \mathbb{D}$ \\ ${ }^{1}$ Sana'a University, Faculty of Petroleum and Natural Resources, Sana'a, Yemen \\ ${ }^{2}$ Sana'a University, Faculty of Engineering, Civil Engineering Department, Sana'a, Yemen
}

Geliş (Received): 23 Aralık (December) 2019, Düzeltme (Revised): 2 Mart (March) 2020, Kabul (Accepted): 17 Mart (March) 2020

\begin{abstract}
Yemen has an appreciable amount of scoria aggregate, but a very small proportion is used as cement additions by local cement factories in blended Portland cement production and very rarely as aggregates into the production of lightweight blocks. Scoria aggregates are widespread in and around the volcanic cones present in Sana'a-Amran volcanic field. This paper presents the results of evaluation of engineering properties of natural scoria, collected from Al-Haweri volcanic cone, NW Sana'a, Yemen as lightweight aggregate. Chemical composition and petrographical characteristics of scoria were determined. The physical properties of the scoria aggregate such as flakiness and elongation indices, specific gravity, water absorption, unit weight, clay lumps and materials finer than $75 \mu \mathrm{m}$ gave acceptable results, but the gradation indicated it would need to be processed before use in a mix. The porosity is high, $60.79 \%$. The Los Angeles abrasion and the aggregate crushing values are higher than the limits of ASTM and BS specification, but the aggregate impact value is close to the upper limits of BS specification. The soundness is within the ASTM specification limits. Therefore, it can be concluded that scoria aggregates can be used to produce structural concrete and masonry blocks with a relatively low density. The scoria aggregates satisfied the requirements of lightweight aggregate for structural concrete and masonry blocks purposes.
\end{abstract}

Keywords: Al-Haweri, Light Weight Aggregate, Scoria Aggregate, Sanaá, Yemen

\section{INTRODUCTION}

Concrete is a composite material that is typically made by combining cement, aggregates, water and often, mineral admixtures in appropriate proportions (Nawy, 2008). It is an essential material used in construction, in which $65 \%$ of its volume is occupied by coarse aggregates (Winsley and Muthukannan, 2018). Therefore, the properties of aggregate including shape, texture, size, moisture content, specific gravity, any intact chemicals, are significant for the properties of concrete.
Lightweight concrete is defined as the concrete of substantially lower unit weight than that made of gravel or normal weight crushed aggregates. The dry densities are normally in the range of 800 to $2000 \mathrm{~kg} / \mathrm{m}^{3}$ (Schlaich and Zareef, 2008). The lightweight concrete has its obvious advantages of high strength/weight ratio, good tensile strength, low coefficient of thermal expansion, and superior heat and sound insulation characteristic due to air voids in lightweight aggregates (Mouli and Khelafi, 2008). Furthermore, the reduction in dead weight of a construction could result in a 
decrease in cross-section of structural members and steel reinforcement (Hossain, 2006; Bozkurt and Yazicioglu, 2015). Lightweight concrete is favourable over normal weight concrete in earthquake prone areas as reducing the dead load of a structure, thus, to reduce the risk of earthquake damages, because the earthquake forces are proportional to the mass of those structures (Yasar et al., 2003; Kilic et al., 2003). The reduction in self-weight will reduce reinforcements (Topcu, 1997) transportation and handling costs. Because of having a large number of voids in the scoria aggregate, possesses a relatively higher thermal insulating efficiency than the normal weight concrete (Al-Jabri et al., 2008), which satisfying ASTM C-332 requirements. The lightness of scoria is due to porousness of the material that is highly sensitive to water content and high water absorption compared to basalt crush rock aggregate. Hence the water-binder ratio in a typical normal concrete mix design is required some adjustments to accommodate this increase in water absorption. However, the porous nature of the aggregate enhances interlocking sites for the cement paste to infiltrate and to form dense uniform interfacial zones between aggregate (Lo and Cui, 2004).

Scoria can be utilized in several industrial applications including the manufacturing of lightweight concrete, as a source of pozzolan to manufacture Portland-pozzolan cement additives, as a heat insulating material, low cost fillers in paint, filter materials, absorbents, architectural applications (Moufti et al., 2000), producing geopolymer mortar (Kamseu et al., 2009; Lemougna et al., 2011; Tchakouté et al., 2015) as a sand in Portland cement mortar (Tchamdjou, et al., 2017; Warati et al., 2019) and cement additives (Al-Anweh, 2010; Al-Akhaly et al., 2018). Scoria, as a cement additive in Portland cement, was found to be effective in improving the property of the cement paste, particularly in controlling the alkali-silica reaction (Hossain, 2006).

Scoria is abundant in various parts of the world such as Turkey (Hossain, 2005; Ozvan et al., 2012), Algeria (Mouli and Khelafi, 2008), Papua New Guinea (Demirdag and Gunduz, 2008; Hossain et al., 2011; Hossain et al., 2015), Syria (Al-Swaidani et al., 2016; Al-Swaidani, 2017), Saudi Arabia (Moufti et al., 1999; Moufti et al., 2000; Sabtan and Shehata, 2000; Alhozaimy et al., 2015), Cameroon (Lemougna et al., 2011; Tchakouté et al., 2015; Juimo et al., 2016; Tchamdjou, et al., 2017), Indonesia (Suseno et al., 2017), Chile (Amigo et al., 2013; González-Maurel et al., 2019), Rwanda (Dieu et al., 2016), Tanzania (Mrema and Mboya, 2013), Ethiopia (Warati et al., 2019) and Mexico (Tchamabé et al., 2020). Scoria is also abundant in Yemen (Al-Sabri, 2009; Al-Anweh, 2010; Al Naaymi, 2015; Al-Akhaly et al., 2018), where more than $9,000 \mathrm{~km}^{2}$ of the country is covered with Quaternary volcanic rocks (Beydoun et al., 1998).

In Yemen, concrete production with conventional building materials is widely used. These types of materials are costly. Structural lightweight concrete is receiving more attention now since it offers the required concrete density, cost saving and reduction of negative environmental effects. Scoria aggregate has highly porous structure and low density. Hence, it can reduce concrete dead load. Currently, in Yemen scoria is used in architectural applications, cement additives, lightweight masonry blocks and road construction as a sub-base material. Therefore, there are several quarries operating on scoria aggregate in NW Sana'a where the Sana'a-Amran volcanic field covers a total area of some $1200 \mathrm{~km}^{2}$. Although scoria has been used 
in the world industry for a long time, it has only had importance in the Yemeni industry for the last 6 years. However, Yemen has an important potential reserve of 1.8 billion $\mathrm{m}^{3}$ (YGSMRB, 2019) with a very small proportion used as a cement addition by local cement factories in blended cement production (e.g. Amran Cement Plant) and as lightweight aggregates. The ability to use scoria in manufacture of cement or lightweight concrete can be an important economic asset.

In Yemen, many geological studies have described the volcanic deposits, but only a few of them have described scoria as a construction material and assessed it for manufacturing lightweight concrete such as Barahim (2009). AlSabri (2009) studied the geology and economic potentiality of scoria deposits in Dhamar-Rada volcanic field. He suggested that scoria deposits are suitable as a lightweight aggregate and cement additive. Al Naaymi (2015) assessment the scoria deposits in Dhamar-Rada volcanic field as pozzolanic materials and lightweight aggregates for producing lightweight concrete and insulation concrete. Two studies were showing the possibility of using scoria in the production of blended cements in Yemen (A1Anweh, 2010; Al-Akhaly et al., 2018).

The estimated reserve of scoria in Sana'aAmran volcanic field is about 411 million $\mathrm{m}^{3}$ (YGSMRB, 2019). To our knowledge, no publishes studies and scientific information are available about the engineering properties of scoria in this volcanic field. Hence, this information would help at present or in the future in other engineering projects which may be used this aggregate.

The current study aims to determine the engineering properties of Al-Haweri scoria, NW Sana'a, Yemen as coarse aggregate.

\section{MATERIALS AND METHODS}

\section{Sample Preparation}

More than $500 \mathrm{~kg}$ of bulk sample was collected from scoria pyroclastic deposits in the Al-Haweri volcanic cone, about $16 \mathrm{~km} \mathrm{NW}$ of Sana'a, Yemen (Figure 1). Three sub-samples were selected from the bulk sample to represent its apparent lithological varieties. These sub-samples were prepared for thin section investigation. Cutting and polishing processes were performed using an oil system. The glue that hardens under UV light was used. To reduce the amount of sample, sampling was performed using the cone and quartering method and riffles, since sampling must have mineralogical, physical and chemical homogeneity. The sample was crushed and ground using a laboratory dodges jaw crusher, rod mill and ball mill to reduce its particle size to sieve $74 \mu \mathrm{m}$ for mineralogical and chemical analyses, which were conducted in Amran Cement Plant (ACP) (Amran/Yemen).

\section{Chemical and Mineral Analysis}

Chemical analysis of three samples of scoria was carried out of by X-ray fluorescence (XRF) of Quality Laboratory of ACP. The preparation of powder pellets for analysis included crushing the samples using a Jaw Crusher, then grinding them to a fine powder using a Disk Vibration Mill. In this stage of sample preparation, about 6-7 $\mathrm{ml}$ of hexane $\left(\mathrm{C}_{6} \mathrm{H}_{14}\right)$ was added to the crushed sample to decrease the temperature during the grinding.

To investigate petrographical characteristics of the sample, thin sections of three representative samples were prepared and studied using the LEICA Polarizing Microscope. These thin sections were carried out in the Geology Department, Faculty of Science, Cairo University, Cairo, Egypt. 
Al-Akhaly, Al-Sakkaf

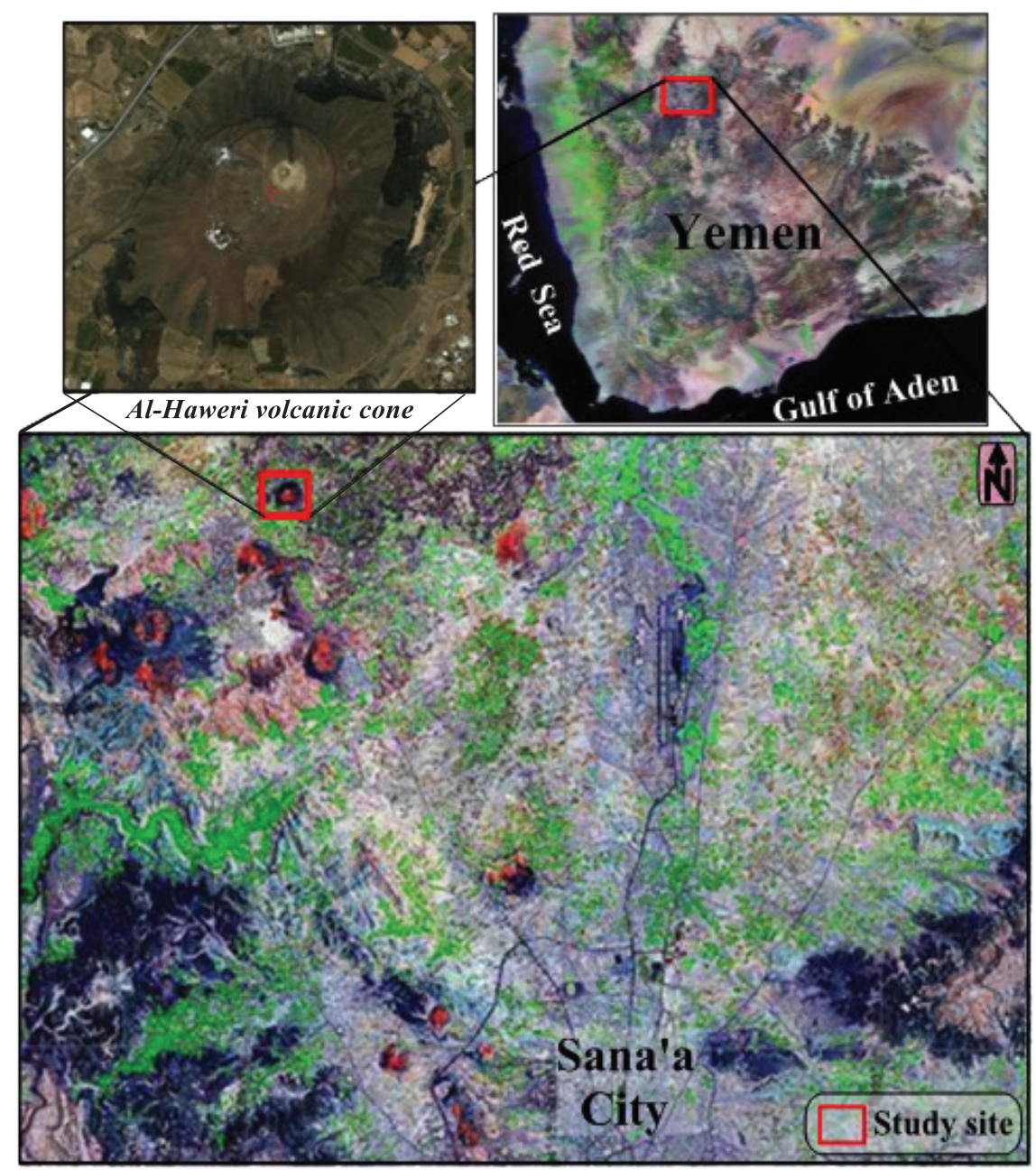

Figure 1. Satellite image showing the location of Al-Haweri volcanic cone.

\section{RESULTS AND DISCUSSION}

\section{Scoria Composition}

Al-Haweri scoria is one of the natural pozzolan volcanic cones in Sanaá-Amran volcanic field that formed during Quaternary explosive eruptions (Figure 1). It has a highly porous structure that was formed by dissolved gases precipitated during cooling as the lava hurtled through the air. Therefore, scoria consists of pyroclastic ejects, of irregular morphology, and has the basic composition of basalt. It formed of vesicular fine to coarse fragments, reddish or black in color and light in weight.

Petrographic investigation shows that the scoria is mainly composed of volcanic glass with phenocrystals of olivine in the matrix and has a hyalopilitic-porphyritic and vitrophyricporphyritic textures with vesicles in the matrix (Figure 2). The thin section studies show that scoria is mainly composed of volcanic glass (amorphous phase). Hence, it well suited as raw materials for the production of aggregates (Juimo et al., 2016). 


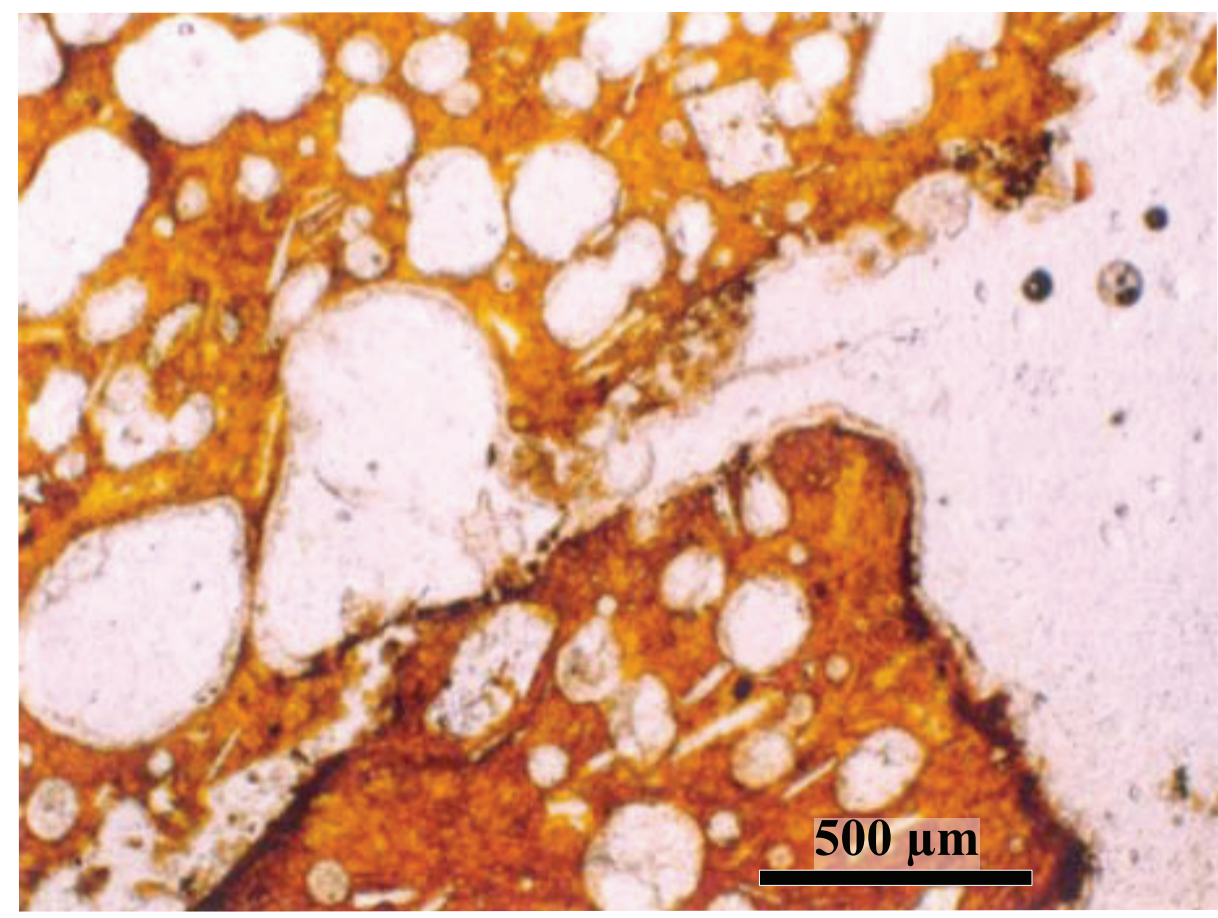

Figure 2. Microphotographs of scoria showing connected and isolated vesicles in the reddish brown glassy groundmass.

Table 1. Chemical composition of scoria aggregate and comparing it with results of several researchers in five different countries.

\begin{tabular}{|c|c|c|c|c|c|c|c|c|c|c|c|c|}
\hline Oxides (\%) & $\mathbf{S i O}_{2}$ & $\mathbf{A l}_{2} \mathbf{O}_{\mathbf{3}}$ & $\mathbf{F e}_{2} \mathbf{O}_{3}$ & $\mathbf{C a O}$ & $\mathbf{M g O}$ & $\mathbf{K}_{\mathbf{2}} \mathbf{O}$ & $\mathbf{N a}_{2} \mathbf{O}$ & $\mathbf{S O}_{3}$ & $\mathbf{P}_{2} \mathbf{O}_{3}$ & $\mathbf{T i O}_{2}$ & LOI & Reference \\
\hline Yemen & 46.60 & 16.68 & 12.41 & 9.23 & 7.84 & 0.88 & 2.65 & 0.05 & 0.37 & 2.11 & 0.82 & This study \\
\hline Cameroon & 47.30 & 14.83 & 13.09 & 8.17 & 6.68 & 1.12 & 3.22 & n.a & n.a. & 2.99 & 0.84 & Billong et al., 2013 \\
\hline Papua New Guinea & 47.50 & 14.00 & 3.50 & 6.50 & 5.00 & 5.00 & n.a. & 0.02 & n.a. & n.a. & 1.40 & Hossain et al., 2015 \\
\hline Syria & 46.52 & 13.00 & 11.40 & 10.10 & 9.11 & 0.77 & 2.14 & 0.27 & n.a. & n.a. & 2.58 & Al-Swaidani, 2017 \\
\hline Ethiopia & 52.53 & 15.49 & 11.00 & 10.11 & 4.40 & $<0.10$ & 2.56 & n.a. & 0.17 & 0.88 & 0.85 & Warati et al., 2019 \\
\hline Chile & 46.40 & 18.50 & 12.90 & 6.50 & 3.00 & 1.10 & 3.50 & n.a. & 0.40 & 1.80 & 6.40 & Amigo et al., 2013 \\
\hline
\end{tabular}

n.a.: Not available.

The results of chemical analysis of the scoria aggregate are given in Table 1 . The chemical composition of the scoria indicates that scoria is mainly composed of $\mathrm{SiO}_{2}(46.60 \%), \mathrm{Al}_{2} \mathrm{O}_{3}$ $(16.68 \%)$ and $\mathrm{Fe}_{2} \mathrm{O}_{3}(12.41 \%)$, a composition that reflects the basic rock quality. The results of the chemical composition of Al-Haweri scoria aggregates are in agreement with the other studies in different countries such as Cameroon, Papua New Guinea, Syria and Chile (Billong et al., 2013; Hossain et al., 2015; Al-Swaidani, 2017 and Amigo et al., 2013) (Table 1). 
This composition is according with American Concrete Institute (ACI) standard on natural pozzolans (ACI, 2000). ASTM designation C-618 (2012) requires that for a material to be accepted as a natural pozzolan, the sum of $\mathrm{SiO}_{2}, \mathrm{Al}_{2} \mathrm{O}_{3}$ and $\mathrm{Fe}_{2} \mathrm{O}_{3}$ should have a minimum value of $70 \%$. Table 1 shows that, total results of $\mathrm{SiO}_{2}, \mathrm{Al}_{2} \mathrm{O}_{3}$ and $\mathrm{Fe}_{2} \mathrm{O}_{3}$ is $75.69 \%$, which is more than the practical conventional value of $70 \%$ in building industry standards (e.g. ASTM C-618, 2012). The rapid cooling of magma in the atmosphere during volcanic eruption is at the origin of the glassy phase in scoria aggregate. The glassy phase content of natural pozzolans is related to the content of $\mathrm{SiO}_{2}$ and $\mathrm{CaO}$ in samples (Millet et al., 1977). When the difference between $\mathrm{SiO}_{2}$ and $\mathrm{CaO}$ content is below 34\%, pozzolans would not include the glassy phase. Al-Haweri scoria aggregates have a difference of $37 \%$. This is a confirmation of the presence of the glassy phase in volcanic pozzolans studied. The presence of that glassy phase would play a major role in the reactivity of the scoria in the presence of $\mathrm{Ca}(\mathrm{OH})_{2}$ and water to form pozzolanic binders (Billong et al., 2013).

\section{Physical Properties of Coarse Scoria}

\section{Particle shape and surface texture}

Particle shape and surface texture of scoria aggregate have been described based on visual examination according to ASTM D-3398-00 and BS 812: Part 1. Particle shape is angular and irregular and surface texture is rough honeycombed. Bonding between aggregate and cement paste depends on the surface of the aggregate. Since the rough surface requires more bonding than the smooth surface, the texture of the studied scoria aggregate complies with the requirement of ASTM and BS standard specifications.
Particle shape affects the performance of aggregate during construction and service. The surface texture of aggregates considerably influences the adhesion between aggregate and cement. In general, a rough surface texture gives good adhesion, whereas a glassy surface results in poor adhesion and the shape of aggregates is an important characteristic since it affects the workability of concrete.

\section{Gradation}

Grading of scoria aggregates was determined by using the procedure of ASTM C-136 to show how the grading of scoria might comply with the grading requirements for the lightweight aggregates for concrete. The results have been used to determine conformance for the particle size distribution with applicable specification requirements. The results of tests are shown in Figure 3. The gradation of Al-Haweri scoria aggregate is well graded and partly fit within the limits stated by the ASTM standards for lightweight aggregate for structural concrete (ASTM C-330), concrete masonry units (ASTM C-331) and insulating concrete (ASTM C-332). The scoria aggregate will need to be blended with the other scoria materials before being used in concrete to fit within the specified limits. The results of gradation were similar to those reported by Moufti et al. (1999) and Sabtan and Shehata (2000) in Saudi Arabia.

Grading of aggregates affects the compaction capacity, permeability and strength of concrete aggregate. It's one of the most important characteristics affecting the stability and workability properties of a mix. Particle shape and size distribution influence the water content necessary to obtain a mix of suitable resistance, and then by affecting the compressive strength, drying shrinkage and durability of the resulting concrete (Engidasew, 2013). 


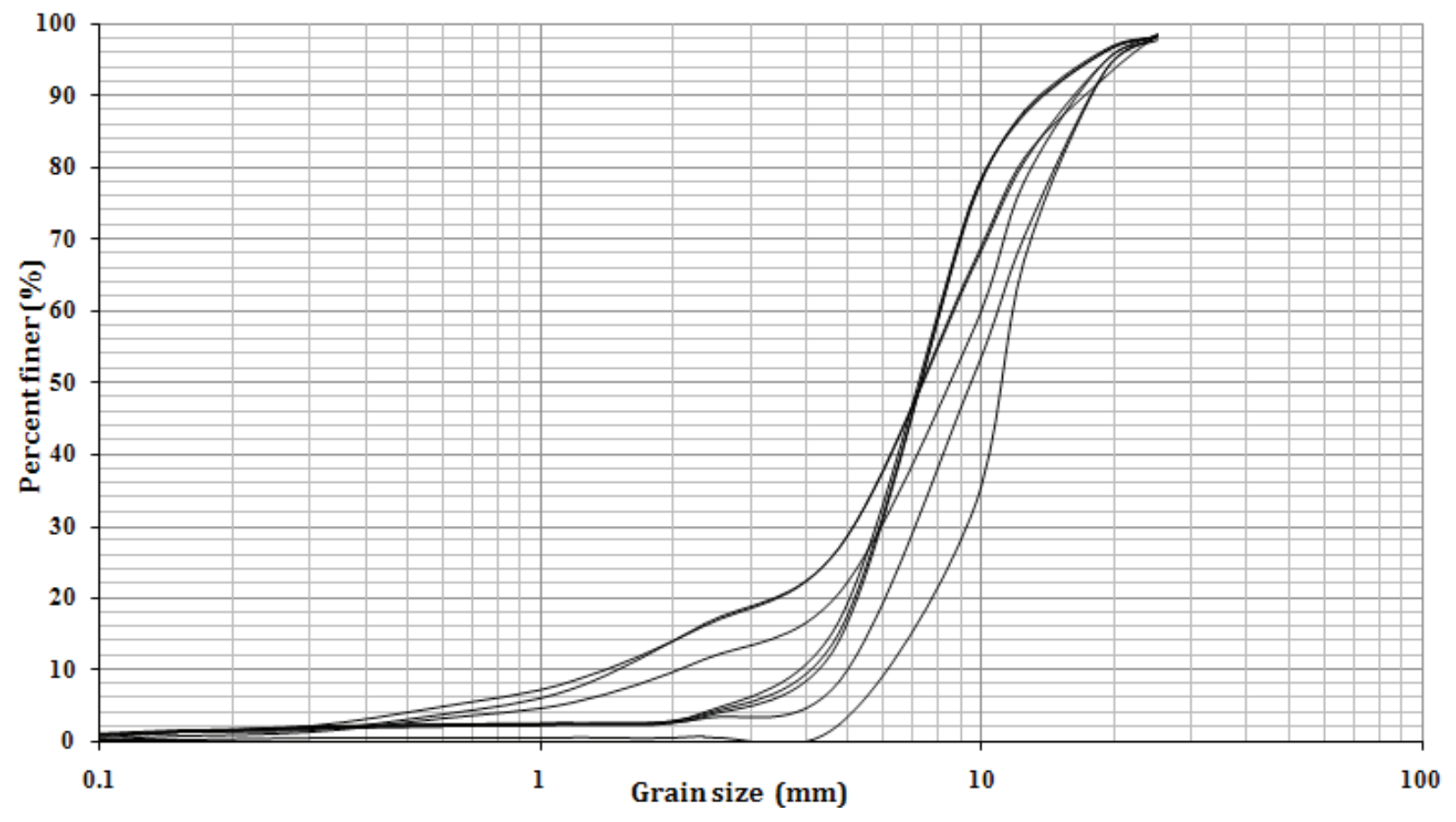

Figure 3. Sieve analysis data for scoria aggregates.

\section{Flakiness and elongation indices}

The flakiness and elongation indices were tested according to BS 812: Part 105 by separating the flaky and elongated aggregate particles by using a metal thickness gauge.

Flaky is a term used as a description for the material with small thickness; relative to the other two dimensions. A flaky particle is one in which the smallest dimension is a maximum of 0.6 times the mean sieve size. An elongated particle is one whose maximum dimension is greater than 1.8 times its mean dimension (BS 812: Part 105).

The flakiness index varies from 2.59 to 4.53 $\%$, with an average of $3.68 \%$ and the elongation index varies from 5.86 to $6.52 \%$, with an average of $6.21 \%$ (Table 2). The flakiness and elongation indices comply the BS 812: Part 105 specifications as concrete aggregate. The results of flaky and elongation indices were lower than those reported by Juimo et al. (2016) in Cameroon.

The presences of flaky and elongated aggregate particles beyond specified limits increase the degradation of mixes and maybe broken during construction.

\section{Specific gravity and water absorption}

The specific gravity and water absorption were carried out according to ASTM C-127. The summary results of specific gravity are shown in Table 2. It is observed that the bulk specific gravity varies from 1.46 to 1.51 , with an average of 1.48 , and apparent specific gravity varies from 1.84 to 1.90 , with an average of 1.86 , which is 
quite satisfactory. The results of bulk specific gravity were nearly similar to that reported by Sabtan and Shehata (2000) in Saudi Arabia and Juimo et al. (2016) in Cameroon and Suseno et al. (2017) in Indonesia and lower than to that reported by Demirdag and Gunduz (2008) in Turkey (Table 2).

The specific gravity of an aggregate is an important factor in the mix design calculation because it relates the weight of aggregate to its volume.

Water absorption represents the water contained in scoria aggregate in saturated surface dry condition. It varies from 12.10 to 15.90 $\%$, with an average of 14.70 (Table 2). Water absorption should not exceed $2.5 \%$ of normal aggregate (ASTM C-127), but can be up to 30 $\%$ for lightweight aggregate (FIB, 1983). The results of water absorption were nearly similar to that reported by other researches (Sabtan and Shehata, 2000; Suseno et al., 2017; Juimo et al., 2016) and lower than those reported by Demirdag and Gunduz (2008) (Table 2).

\section{Porosity}

The porosity (n) of the scoria aggregate was calculated using the following equation:

$$
\mathrm{n}=\frac{\mathrm{e}}{1+\mathrm{e}}
$$

where

$$
\mathrm{e}=\frac{\mathrm{G} \gamma_{\mathrm{w}}}{\gamma_{\mathrm{dry}}}-1
$$

$\mathrm{G}$ is the apparent specific gravity

$\gamma_{w}$ is the density of water in $\mathrm{g} / \mathrm{cm}^{3}$

$\gamma_{\text {dry }}$ is the dry density of scoria in $\mathrm{g} / \mathrm{cm}^{3}$

The calculated porosity values ranged between 59.78 and $61.26 \%$, with an average of $60.79 \%$ (Table 2). These values are highly compared with other lightweight aggregates except pumice aggregates. This means that AlHaweri scoria aggregates have the largest pore volume; a lot pores unconnected with the outer surface and thus the lowest water absorption. Because of these unconnected pores, the water absorption is very low. Scoria aggregates have a larger pore volume than normal weight aggregates. Therefore, the rate of water absorption is likely to be higher than for normal aggregates.

The results of porosity were slightly similar to that reported by Demirdag and Gunduz (2008) and lower than to that reported by Sabtan and Shehata (2000), Juimo et al. (2016) and Suseno et al. (2017) (Table 2).

\section{Unit weight}

The unit weight of the scoria aggregate was performed according to ASTM C-29/C-29M. The average loose unit weight is $657 \mathrm{~kg} / \mathrm{m}^{3}$, while the average compacted unit weight is $735 \mathrm{~kg} / \mathrm{m}^{3}$ (Table 2). These results within the requirement for lightweight aggregate for structural concrete (ASTM C-330), concrete masonry units (ASTM C-331) and insulating concrete (ASTM C-332).

The results of the loose unit weight were slightly lower than that reported by Sabtan and Shehata (2000) and Suseno et al. (2017) and slightly higher than to that reported by Juimo et al. (2016) and Demirdag and Gunduz (2008), while the results of the compacted unit weight were slightly lower than that reported by Sabtan and Shehata (2000) and Juimo et al. (2016) (Table 2). 
Table 2. Some engineering properties of coarse scoria aggregates and comparing with different authors.

\begin{tabular}{|c|c|c|c|c|c|c|c|c|c|}
\hline \multirow{2}{*}{\multicolumn{2}{|c|}{$\begin{array}{c}\text { Engineering properties } \\
\text { min. }\end{array}$}} & \multicolumn{3}{|c|}{ This study } & \multirow{2}{*}{$\begin{array}{c}\qquad 1] \\
\text { Saudi Arabia }\end{array}$} & \multirow{2}{*}{$\begin{array}{c}\text { [2] } \\
\text { Turkey }\end{array}$} & \multirow{2}{*}{$\begin{array}{c}{[3]} \\
\text { Cameroon } \\
\end{array}$} & \multirow{2}{*}{$\begin{array}{l}\quad[4] \\
\text { Indonesia }\end{array}$} & \multirow{2}{*}{$\begin{array}{c}\text { Standard (Acceptance } \\
\text { limits) }\end{array}$} \\
\hline & & Max. & Ave. & & & & & & \\
\hline \multicolumn{2}{|c|}{$\begin{array}{c}\text { Aggregate size range } \\
(\mathrm{mm})\end{array}$} & 4.75 & 25.4 & - & $4.75-19$ & $4-8$ & $5-18$ & $4.75-19$ & \\
\hline \multicolumn{2}{|c|}{$\begin{array}{c}\text { Flaky index } \\
(\%)\end{array}$} & 2.59 & 4.53 & 3.68 & - & - & 21 & - & $<25 \%$ \\
\hline \multicolumn{2}{|c|}{$\begin{array}{c}\text { Elongation index } \\
(\%)\end{array}$} & 5.86 & 6.52 & 6.21 & - & - & 12 & - & [BS 812: Part 105] \\
\hline \multirow{3}{*}{$\begin{array}{l}\text { Specific } \\
\text { gravity }\end{array}$} & Bulk & 1.46 & 1.51 & 1.48 & 1.58 & 2.7 & 1.58 & 1.72 & \\
\hline & Apparent & 1.84 & 1.90 & 1.86 & 1.78 & - & - & - & \\
\hline & Saturated & 1.69 & 1.70 & 1.69 & 1.98 & - & - & - & \\
\hline \multicolumn{2}{|c|}{$\begin{array}{c}\text { Water absorption } \\
(\%)\end{array}$} & 12.10 & 15.90 & 14.70 & 13.10 & 22.16 & $12-28$ & 12.27 & $\begin{array}{c}<30 \% \\
{[\text { FIB 1983] }}\end{array}$ \\
\hline \multicolumn{2}{|c|}{$\begin{array}{c}\text { Porosity } \\
(\%)\end{array}$} & 59.78 & 61.26 & 60.79 & 43 & 57.21 & 51 & - & \\
\hline \multirow{2}{*}{$\begin{array}{c}\text { Unit } \\
\text { weight } \\
\left(\mathbf{k g} / \mathbf{m}^{3}\right)\end{array}$} & Loose & 649 & 663 & 657 & 776 & 572 & 560 & 850.12 & \multirow{2}{*}{$\begin{array}{c}\leq 880 \mathrm{~kg} / \mathrm{m}^{3} \\
\text { [ASTM C-330, C-331 } \\
\text { and C-332] }\end{array}$} \\
\hline & Compacted & 735 & 740 & 735 & 866 & - & 820 & - & \\
\hline \multicolumn{2}{|c|}{$\begin{array}{l}\text { Clay lumps } \\
(\%)\end{array}$} & 0.50 & 1.60 & 1.17 & 1.30 & \multirow{2}{*}{4.10} & - & - & $\begin{array}{c}\leq 2 \% \\
{[\text { ASTM C-33, C-330 and }} \\
\text { C-331] }\end{array}$ \\
\hline \multicolumn{2}{|c|}{$\begin{array}{c}\text { Materials }<75 \mu \mathrm{m} \\
(\%)\end{array}$} & 0.40 & 0.90 & 0.62 & 2 & & - & - & $\begin{array}{c}\leq 1 \% \\
{[\text { ASTM C-33] }}\end{array}$ \\
\hline \multicolumn{2}{|c|}{$\begin{array}{l}\text { Loss on ignition, LOI } \\
(\%)\end{array}$} & 0.65 & 1.00 & 0.81 & 1.41 & $=$ & 0.2 & - & $\begin{array}{c}\leq 5 \%[ \\
\text { ASTM C-330, C-331 and } \\
\text { C-332] }\end{array}$ \\
\hline \multicolumn{2}{|c|}{$\begin{array}{l}\text { Soundness } \\
(\%)\end{array}$} & 1.80 & 3.17 & 2.70 & 4.30 & $=$ & - & - & $\begin{array}{c}\leq 12 \% \\
{[\text { ASTM C-33] }}\end{array}$ \\
\hline \multicolumn{2}{|c|}{$\begin{array}{c}\text { Los Angeles abrasion } \\
\text { value, LAAV (\%) }\end{array}$} & 48.72 & 59.70 & 54.63 & 55.40 & $=$ & - & 58.5 & $\begin{array}{c}\leq 50 \% \\
{[\text { ASTM C-33] }}\end{array}$ \\
\hline \multicolumn{2}{|c|}{$\begin{array}{c}\text { Aggregate crushing } \\
\text { value, } \operatorname{ACV}(\%)\end{array}$} & 55.11 & 63.01 & 59.39 & - & $=$ & - & 48.37 & \multirow{2}{*}{$\begin{array}{l}\leq 25 \% \text { for heavy duty } \\
\text { concrete floor finishes } \\
\leq 30 \% \text { for pavement } \\
\text { wearing surfaces } \\
\leq 45 \% \text { for others } \\
\text { [BS } 812 \text { : Part } 110 \text { and } \\
112]\end{array}$} \\
\hline \multicolumn{2}{|c|}{$\begin{array}{l}\text { Aggregate impact } \\
\text { value, AIV (\%) }\end{array}$} & 37.50 & 44.90 & 41.79 & 40.20 & - & - & - & \\
\hline
\end{tabular}

[1] Sabtan and Shehata, 2000; [2] Demirdag and Gunduz, 2008; [3] Juimo et al., 2016; [4] Suseno et al., 2017.

\section{Clay lumps and friable particles}

The clay lumps content in scoria aggregate was determined according to ASTM C-142. Its content ranged between 0.50 and $1.60 \%$ with an average of $1.17 \%$ (Table 2). These values within the acceptable standard specification limits of lightweight aggregates of $2 \%$ for structural concrete (ASTM C-330), concrete masonry units 
Al-Akhaly, Al-Sakkaf

(ASTM C-331) and insulating concrete (ASTM C-332). The results of clay lumps were similar to those reported by Sabtan and Shehata (2000) in Saudi Arabia and lower than to that reported by (Demirdag and Gunduz, 2008) in Papua New Guinea (Table 2).

The clay lumps and friable particles in scoria aggregate are unacceptable because, they can break up during mixing and thereby absorb some of the mixing water, cause popouts in hardened concrete and affect the durability and wear resistance.

\section{Materials finer than $75 \mu \mathrm{m}$}

The materials finer than $75 \mu \mathrm{m}$ which represents the dust in the scoria aggregate was tested according to ASTM C-117. The percentage of the materials finer than $75 \mu \mathrm{m}$ ranged between 0.40 and $0.90 \%$ with an average of $0.62 \%$ (Table 2). These results indicate that; the scoria aggregates are complying with the specification limits (ASTM C-33) $(<1 \%)$. The results were lower than to that reported by Sabtan and Shehata (2000) in Saudi Arabia, 2\%.

The materials finer than $75 \mu \mathrm{m}$, especially silt and clay, may form a coating on the aggregate particles. Even thin coatings of silt or clay on scoria aggregates can be harmful because it might weaken the bond between the cement paste and the aggregate.

The use of weathered and altered scoria as lightweight aggregates in constructions may cause premature failures in-service. Several researchers such as Van Atta and Ludowise (1976); Van Rooy (1991); Lagerblad and Jacobsson (1997) relate this failure to the presence of smectite minerals in the aggregates used. Smectite is a fairly common secondary product in the basalt, resulting from low-grade alteration and weathering. The presence of smectite increases drying shrinkage of mortar samples when present in aggregates that were used in concrete (Sveinsdottir et al., 1999). The reported failure mechanisms include the release of plastic fines and the potential of these minerals to expand and contract upon moisture fluctuations.

\section{Loss on ignition}

The loss on ignition (LOI), for the scoria was carried out by XRD. The average of LOI for the scoria aggregate ranged between 0.65 and $1 \%$ with an average of $0.81 \%$ (Table 2). According to ASTM C-114, LOI of aggregates, consisting of end products of coal or coke combustion, should not exceed $12 \%$, while LOI of other aggregates should not exceed $5 \%$, which indicates that, the study scoria aggregate are within acceptable specification limits. LOI measures the proportion of hydrated minerals in the aggregates.

\section{Mechanical Properties of Scoria}

\section{Los Angeles abrasion value}

The Los Angeles abrasion value (LAAV) test was determined according to ASTM C-131. Its value ranges between 48.72 and $59.70 \%$ with an average of $54.63 \%$ (Table 2). These values are higher than the limits of ASTM specification, as the LAAV should not exceed $50 \%$ (ASTM C-131). The results were similar to those reported by Sabtan and Shehata (2000) and relatively lower than those reported by Suseno et al. (2017) (Table 2).

Abrasion resistance is essential when the aggregate is to be used in concrete subject to abrasion as in heavy-duty floors or pavements. The LAAV would not be unacceptable for normal aggregate, but there are no required specifications for lightweight aggregate. This test 
was performed only for the sake of comparison. Low abrasion resistance of scoria aggregate increases the quantity of fines in the concrete during mixing and consequently may increase the water requirement.

\section{Aggregate crushing value}

The aggregate crushing value (ACV) test was tested according to BS 812: Part 110. Its value ranges between 55.11 and $63.01 \%$ with an average of $59.39 \%$ (Table 2). These values are higher than the limits of BS specification, as the ACV should not exceed $45 \%$ (BS 812: Part 110). The results were higher than those reported by Suseno et al. (2017), 48.37\% (Table 2). The ACV test measures the resistance of an aggregate to disintegration under gradually applied load.

\section{Aggregate impact value}

The aggregate impact value (AIV) test was carried out according to BS 812: Part 112. Its value ranges between 37.50 and $44.90 \%$ with an average of $41.79 \%$ (Table 2). These values are close to the upper limits of BS specifications. Scoria aggregate lies within the specified limits, as the AIV should not exceed $45 \%$ (BS 882: Part 112). The results similar to that reported by Sabtan and Shehata (2000) in Saudi Arabia, 40.20 (Table 2).

The AIV gives a relative measure of the resistance of an aggregate to a sudden shock or impact. Impact resistance is essential when the aggregate is to be used in concrete subject to a sudden impact as in airports or seaports.

The LAAV, ACV and AIV of an aggregate are often used as a general index of its quality. They are carried out for scoria aggregate in this study for the sake of comparison.
It should be noted that the ASTM or BS concerning the mechanical properties of the lightweight aggregate for use in lightweight concretes had laid no specification requirement limits and the used limits are those for normal concrete.

\section{Soundness}

Soundness test was performed according to ASTM C-88 using sodium sulphate $\left(\mathrm{Na}_{2} \mathrm{SO}_{4}\right)$ method. Scoria aggregates have shown very good results ranging from 1.80 to $3.17 \%$ with an average of $2.70 \%$ (Table 2 ). These results are quite good according to the ASTM specifications $(<12 \%)$. The results were lower than those reported by Sabtan and Shehata (2000) in Saudi Arabia, $4.3 \%$.

The soundness test evaluates the resistance of aggregate to disintegrate when subjected to attacks by salts and freeze and thaw action during extreme weathering conditions (Wu et al., 1998). Freezing and thawing cycles are simulated by immersing the aggregate in a sulphate solution, drying the aggregate, and then reimmersing the aggregate in the sulphate solution. Expansive forces are created when the sulphate crystals in the aggregate pores are re-hydrated. The salt expansion simulates the forces that are created when water freezes in aggregate pores.

\section{CONCLUSIONS AND RECOMMENDATIONS}

Al-Haweri scoria consists of vesicular fine to coarse fragments, light in weight and has the basic composition of basalt. It can be classified as rough honeycombed extremely angular materials with acceptable flakiness and elongation indices. Scoria aggregate is well graded and partly fit within the limits stated by 
the ASTM for lightweight aggregate but mixing and possible crushing is required to prepare an acceptable grading. The specific gravity is low and the water absorption is high. The unit weight is low and complies with the requirement for lightweight aggregates for structural concrete, concrete masonry units and insulating concrete. The clay lumps content, the materials finer than $75 \mu \mathrm{m}$, LOI and soundness are within the ASTM specification limits.

The LAAV and ACV are higher than the limits of the ASTM and BS specifications and not acceptable, but the AIV is close to the upper limits of BS specifications.

This investigation proves a potential use of Al-Haweri scoria as coarse aggregate to produce lightweight concrete. Scoria will provide engineers with an alternative for conventional concrete with a reduced dead load.

Scoria deposit is a raw material treasure for Yemen. Accordingly, similar studies should be carried out in different localities within the Quaternary volcanic fields and investigate scoria's use as thermal and sound insulation, abrasive, absorbent, filler in paint, producing geopolymer mortar, fine aggregate (as sand) and manufacturing of rock wool.

\section{REFERENCES}

ACI, 2000. Use of raw or processed natural Pozzolans in Concrete, ACI Committee 232, Manual of Concrete Pratice ACI 232.1.

Al-Akhaly, I.A., Al-Anweh, A.M., El-Anbaawy, M.I., 2018. Preliminary assessment of utilization of Al-Jaif Scoria (NW Sana'a, Yemen) for cement production. SQU Journal for Science, 23(2), 111-119. doi:http://dx.doi.org/10.24200/squjs. vol23iss 2.

Al-Naaymi, T.A., 2015. Assessment of pumice and scoria deposits in Dhamar-Rada' volcanic field SW- Yemen, as a pozzolanic materials and lightweight aggregates. International Journal of Innovative Science, Engineering and Technology, 2(9), 386-402.

Al-Anweh, A.M., 2010. Geology and cement industrial applications on carbonate and clay deposits around Sana'a basin, Republic of Yemen. MSc. Thesis, Geology Department, Faculty of Science, Cairo University, Egypt.

Alhozaimy, A., Fares, G., Alawad, O.A., AlNegheimish, A., 2015. Heat of hydration of concrete containing powdered scoria rock as a natural pozzolanic material. Construction and Building Materials, 81, 113-119.

Al-Jabri, K.S., Hag, A.W., Al -Nuaimi, A.S., Al Saidy, A.H., 2008. Concrete blocks for thermal insulation in hot climate. Cement and Concrete Research, 35, 1472-1479.

Al-Sabri, A.M., 2009. Geology and economic potentiality of the scoria deposits in DhamarRada volcanic field, Yemen. Ph.D. Thesis, Sana'a University, Faculty of Science, Earth and Environmental Science Department.

Al-Swaidani, A.M., 2017. Production of more durable and sustainable concretes using volcanic scoria as cement replacement. Materiales de Construcción, 67(326):e118 http://dx.doi.org/ 10.3989/mc.2017.00716.

Al-Swaidani, A.M., Aliyan, S.D., Adarnaly, N., 2016. Mechanical strength development of mortars containing volcanic scoria-based binders with different fineness. Engineering Science and Technology, an International Journal, 19 (2), 970-979.

Amigo, Á., Lara, L., Smith, V., 2013. Holocene record of large explosive eruptions from Chaitén and Michinmahuida volcanoes, Chile. Andean Geology, 40 (2), 227-248. doi: 10.5027/ andgeoV40n2-a03.

ASTM C33 / C33M-18. 2018. Standard specification for concrete aggregates, ASTM International, West Conshohocken, PA.

ASTM C88-99a. 1999. Standard test method for soundness of aggregates by use of sodium sulfate 
or magnesium sulfate, ASTM International, West Conshohocken, PA.

ASTM C127-01. 2001. Standard test method for density, relative density (specific gravity), and absorption of coarse aggregate, ASTM International, West Conshohocken, PA.

ASTM C131-06. 2006. Standard test method for resistance to degradation of small-size coarse aggregate by abrasion and impact in the Los Angeles Machine, ASTM International, West Conshohocken, PA.

ASTM C136-01. 2001. Standard test method for sieve analysis of fine and coarse aggregates, ASTM International, West Conshohocken, PA.

ASTM C618-12. 2012. Standard specification for coal fly ash and raw or calcined natural pozzolan for use in concrete, ASTM International, West Conshohocken, PA.

ASTM D3398-00. 2000. Standard Test Method for Index of Aggregate Particle Shape and Texture, ASTM International, West Conshohocken, PA.

Barahim, A.M., 2009. Comparing compressive strength of concrete by using light weight aggregate (Scoria-Tuff volcanic) from Alargoub area with concrete of normal coarse aggregate. 2nd Engineering Conference, Faculty of Engineering, Aden University, Aden, Yemen.

Beydoun, Z.R., As-Saruri, M.A., El-Nakhal, H., Al-Ganad, I.N., Baraba, R.S., Nani, A.O., AlAawah, M.H., 1998. International Lexicon of Stratigraphy, Republic of Yemen. IUGS and Ministry of Oil and Mineral Resources, Sana'a, Republic of Yemen. 245p.

Billong, N., Melo, U.C., Njopwouo, D., Louvet, F., and Bonnet, J.P., 2013. Physicochemical characteristics of some cameroonian pozzolans for use in sustainable cement like materials. Materials Sciences and Applications, 4, 14-21. http://dx.doi.org/10.4236/msa.2013.41003.

Bozkurt, N., Yazicioglu, S., 2015. Sustainable structural lightweight concrete design and the investigation of the mechanical properties. Bitlis Eren University Journal of Science \& Technology, 5(2), 62-67.
BS 812: Part 1. 1975. Methods for determination of particle size and shape. British Standards Institution, London, UK.

BS 812: Part 2. 1975. Determination of relative densities and water absorption of coarse aggregates. British Standards Institution, London, UK.

BS 812: Part 105.1. 1989. Determination of aggregate particle shape (flakiness index). British Standards Institution, London, UK.

BS 812: Part 105.2. 1989. Determination of aggregate particle shape (elongation index). British Standards Institution, London, UK.

BS 812: Part 112. 1990. Methods for determination of aggregate impact value (AIV). British Standards Institution, London, UK.

Demirdag, S., Gunduz, L., 2008. Strength properties of volcanic slag aggregate lightweight concrete for high performance masonry units. Construction and Building Materials, 22, 135-142.

Dieu, M.J., Pranesh, M.R., Wali, U.G., 2016. Engineering characteristics of volcanic rock aggregates of Rwanda. International Journal of Civil Engineering and Technnology, 7(3), 81-90.

Engidasew, T.A., 2013. Engineering geological characterization of volcanic rocks of Ethiopian and Sardinian highlands to be used as construction materials. Ph.D. Thesis, Università degli Studi di Cagliari. Cagliari, Italy (unpublished).

FIB, 1983. FIB manual of light weight aggregate concrete. $2^{\text {nd }}$ edition, Surrey University Press, Galasgow, 259p.

González-Maurel, O., Godoyc, B., Rouxb, P., Rodríguez, I, Maríne, C., Menzies, A., Bertin, D., Morata, D., Vargas, M., 2019. Magmatic differentiation at La Poruña scoria cone, Central Andes, northern Chile: Evidence for assimilation during turbulent ascent processes, and genetic links with mafic eruptions at adjacent San Pedro volcano. Lithos, 338-339:128-140.

Hossain, K.M.A., 2005. Volcanic ash and pumice as cement additives: pozzolanic, alkali-silica reaction and autoclave expansion characteristics. Cement and Concrete Research, 35, 1141-1144. 
Hossain, K.M.A., 2006. Blended cement and lightweight concrete using scoria: mix design, strength, durability and heat insulation characteristics. Physical Sciences, 1, 5-16.

Hossain, K.M.A, Ahmed, S., Lachemi, M., 2011. Lightweight concrete incorporating pumice based blended cement and aggregate: mechanical and durability characteristics, Construction and Building Material, 25, 1186-1195.

Hossain, K.M.A., Julkarnine, K.M., Anwar, M.S., 2015. Evolution of strength and durability of scoria concrete in sea environment. Journal of Multidisciplinary Engineering Science and Technology, 2(6), 1268.

Kamseu, E., Leonelli, C., Perera, D.S., Melo, U.F., Lemougna, P.N., 2009. Investigation of volcanic ash-based geo-polymers as potential building materials. Ceramics International, 58(2), 136140 .

Kilic, A., Atis, C.D., Yasar, E., Ozcan, F., 2003. High-strength lightweight concrete made with scoria aggregate containing mineral admixtures. Cement and Concrete Research, 33, 1595-1599.

Juimo, W., Cherradi, T. Abidi, L., Oliveira L., 2016. Characterisation of natural pozzolan of "Djoungo" (Cameroon) as lightweight aggregate for lightweight concrete. International Journal of GEOMATE, 11(27), 2782-2789.

Lagerblad, B., Jacobsson, B., 1997. Smectite clays and concrete durability. Proceedings 19 th. International Conference Cement Microscopy, 151-162.

Lemougna, P.N., MacKenzie, K.J., Melo, U.F., 2011. Synthesis and thermal properties of inorganic polymers (geopolymers) for structural and refractory applications from volcanic ash. Ceramics International, 37(8), 3011-3018. doi:10.1016/j.ceramint.2011.05.002.

Lo, T.Y., Cui, H.Z., 2004. Effect of porous lightweight aggregate on strength of concrete. Materials Letters, 58, 916-919.

Moufti, M.R., Sabtan A.A., El-Mahdy O.R., Shehata, W.M., 1999. Preliminary geological and engineering assessment of the pyroclastic deposits in the central part of Harrat Rahat. JKAU: Earth Sciences, 11, 59-88.

Moufti, M.R., Sabtan A.A., El-Mahdy O.R., Shehata, W.M., 2000. Assessing of industrial utilization of scoria materials in the central Harrat Rahat, Saudi Arabia. Engineering Geology, 57, 155162.

Mouli, M., Khelafi, H., 2008. Performance characteristics of lightweight aggregate concrete containing natural pozzolan, Building and Environment, 43, 31-36.

Mrema, A.L., Mboya, H.A., 2013. Feasibility of lightweight aggregate concrete for structural and non-structural works in Tanzania, (Zingoni, A. (Ed.in Research and Applications in Structural Engineering, Mechanics and Computation. London: CRC Press), Chapter 293, 2 pages.

Nawy, E.G., 2008. Concrete construction engineering handbook, 2nd edition, CRC Press, Boca Raton.

Ozvan, A., Tapan, M., Erik, O., Efe, T., Depci, T., 2012. Compressive strength of scoria added portland cement concretes. Gazi University Journal of Science, 25(3), 769-775.

Sabtan, A.A., Shehata, W.M., 2000. Evaluation of engineering properties of scoria in central Harrat Rahat, Saudi Arabia. Bulletin of the Engineering Geology and the Environment, 59, 219-225.

Schlaich, M., Zareef, M.E. 2008. Infra-lightweight concrete. Taylor \& Francis Group, London, ISBN 978-0-415-47535-8.

Suseno, H., Soehardjono, A., Wardana, I., Rachmansyah, A., 2017. Suitability of medium-K basaltic andesite pumice and scoria as coarse aggregates on structural lightweight concrete. International Journal of Engineering and Technology, 9(4), 3318-3329. doi: 10.21817/ ijet/2017/v9i4/170904103.

Sveinsdottir, E.L., Magnusdottir, B., Hardardottir, V., Holmgeirsdottir, T., Kristmannsdottir, H., Tryggvason, N., 1999. The effect of alteration minerals on the quality of construction aggregates (in Icelandic). IBRI Report No. 99-01, 53p. 
Tchakouté, H.K., Kong, S., Djobo, J.N., Tchadjié, L.N., Njopwouo, D., 2015. A comparative study of two methods to produce geopolymer composites from volcanic scoria and the role of structural water contained in the volcanic scoria on its reactivity. Ceramics International, 41p.

Tchamabé, B.C., Carrasco-Núñeza, G., Miggins, D.P., Németh, K., 2020. Late Pleistocene to Holocene activity of Alchichica maar volcano, eastern Trans-Mexican Volcanic Belt. Journal of South American Earth Sciences, 97, 102404.

Tchamdjou, W.H., Grigoletto, S., Michel, F., Courard, L., Abidi, M.L., Cherradi, T., 2017. An investigation on the use of coarse volcanic scoria as sand in Portland cement mortar. Case Studies in Construction Materials, 7, 191-206.

Topcu, İ. B., 1997. Semi lightweight concretes produced by volcanic slags. Cement and Concrete Research, 27, 15-21.

Van Atta, R.O., Ludowise H., 1976. Causes of degradation in basaltic aggregates and durability testing. 14th Engineering Geological and Soils Engineering Symposium, 241-254.
Van Rooy, J. L., 1991. The influence of the mineralogy on the durability of Drakensberg basalts. In Blight et al.: Geotechnics, in the African Environment, 383-392.

Warati, G. K., Darwish, M.M., Feyessa, F.F., Ghebrab, T., 2019. Suitability of scoria as fine aggregate and its effect on the properties of concrete. Sustainability, 11, 4647, doi:10.3390/ su11174647.

Winsley, J. B., Muthukannan, M., 2018. A preliminary study on the physical properties of an alternative coarse aggregate made with red soil and fly ash. The Open Construction and Building Technology Journal, 12, 1-8. doi: 10.2174/1874836801812010001.

Yasar, E., Atis, C.D., Kilic, A., Gulsen, H., 2003. Strength properties of lightweight concrete made with basaltic pumice and fly ash. Materials Letters, 57, 2267-2270.

YGSMRB, 2019. Yemen Geological Survey and Mineral Resources Board, www.ygsmrb.org.ye (accessed on 7 Dec. 2019). 